\title{
新课标下初中数学教学质量提升路径探析
}

刘盛辉

江西省瑞金市下坝初级中学

DOI:10.32629/jief.v2i5.1426

[摘 要] 初中数学是初中教学的重要组成部分。它对于培养学生学习数学的良好习惯, 培养学生的数学思维能力, 提高学生的核心素质具有 极其重要的作用。然而, 数学课堂教学质量普遍不高, 极大地影响了学生的学习兴趣, 阻碍了学生对数学的追求, 减缓了学生求知的步伐。 如何提高课堂教学的质量和效率, 已成为广大数学教师需要思考的问题。

[关键词] 新课程改革; 初中数学; 教学效果; 实施策略

中图分类号: G633.6 文献标识码: A

随着新课程改革的发展, 教师越来越重视数学教学的效果, 将提升 数学教学效果提上工作日程, 积极引导学生明确教材所讲授的内容, 实 施科学的、合理的教育理念, 树立起正确的教育目标。

\section{1 新课程标准提高初中数学课堂教学的基本内涵}

1.1 新课程改革加入到数学课堂教学当中, 培养学生形成良好的思 维能力, 引导学生进行独立的思考, 让学生逐渐可以自主思考教材的内 容, 形成预习、复习等良好的学习习惯, 满足新课程改革的需求, 紧紧 追随时代发展的步伐, 掌握到坚实的数学知识基础, 可以自主解决学习 上遇到的问题, 深入探索出问题的答案。

1.2 新课程标准教学建立起以学生为主体的课堂教学形式, 突出学 生在课堂上的主体地位, 使教师明确每一个学生之间存在的个体差异性, 充分尊重学生的个性化发展, 分析出学生所具有的不同的兴趣爱好, 根 据他们不同的兴趣爱好进行分类教学, 积极采用因材施教的教学原则, 提升全体学生的学习质量和效果。

\section{2 提高在新课程标准下初中数学课堂教学效果实施的具体策略}

2.1 恰当地使用数学语言, 做到知识传递的准确性

在数学课堂上, 教师应积极满足新课程标准提出的要求, 使用恰当 的语言进行教学, 采用规范化的语言形式, 利用简洁的语言去简化教材 的内容, 准确地叙述出数学公式的含义, 严谨地讲解每一个数学教材内 容上的知识点, 带领学生学习到正确的数学知识, 促使他们准确地掌握 到教材的内容。同时, 教师一定要注意自身说话的语气和语调, 实现内 容讲解的趣味性, 展现出形象、有趣的语言形式, 利用通俗易懂的话语 去引领学生投入到学习当中, 让学生充分理解抽象的数学知识, 乐于学 习教材上的内容。例如, 在《相交线与平行线》这一课学习当中, 教师 利用 “人的关系” 来比喻相交线与平行线之间的关系, 准确地解读相交 线与平行线的基本定义, 让学生直观地感受到相交线与平行线的含义, 了解到两条直线的相互关系。

2.2 增加合作探究学习方式, 增强学生的合作与交流

为满足新课标的改革与实施, 教师创建出小组合作探究学习方式, 将每 5 个学生分为一个学习小组, 在分组时做到将学生学习能力进行平 均分配, 保持小组之间学习能力的平衡性, 激发每一个学生对知识的探 索欲望, 让每一个学生都能主动加入到小组合作交流过程当中, 自主观 察数学理论的形式过程, 大胆猜测教材内容的形成理念, 自主验证猜测 内容的正确性, 从而提升学生对数学知识的把握能力, 促进小组成员之
间的合作与交流。

2.3 强化课堂训练内容, 增强学生对知识的掌握

在新课标下, 教师强化课堂教学的训练内容, 优化课堂训练的形式, 注重课堂训练的基础性, 建立起训练内容的层次性, 将训练内容应用到 实际生活当中, 增加训练的实用性和实效性, 从而提升学生的理解能力, 增强课堂教学的效果。教师要建立起具有趣味性的训练形式, 充分激发 学生的学习热情, 调动他们学习的积极性, 提升他们对教材内容的掌握 程度, 有效巩固了学生数学知识的基础。

2.4 改善课堂教学方式, 提升学生的问题意识

在教学过程中, 教师积极转变传统的教学态度, 改善课堂教学的方 式方法, 创设出问题情境教学形式, 利用问题去引导学生进行思考, 让 学生带着问题去了解教材的主要内容, 切实解决教材中存在的问题, 将 抽象的知识变得形象化和针对化, 有助于提升学生的问题意识, 增强他 们对教材内容的理解和掌握, 提高课堂教学的效果。例如, 在《探索轴 对称的性质》这一课学习当中, 教师建立起问题教学方法, 对学生提出 以下问题: “轴对称图形的性质是什么”、“什么样的图形可以成为轴对称 图形”, 让学生带着问题去思考轴对称图形所具有的性质, 了解到轴对称 图形的特点, 可以自主完善轴对称图形的画法, 从而提高学生的思维能 力, 增强他们解决问题的能力。

\section{3 结束语}

在新课标下, 数学课堂教学紧紧追随时代发展的步伐, 积极使用现 代化的教学工具。教师积极使用恰当的语言进行教学, 丰富课堂教学的 形式, 强化课堂训练的内容, 创建出生动形象的情境教学模式, 建立起 合作探究的学习方式, 有效地激发学生的学习兴趣, 增强他们的学习能 力, 降低了教师对数学知识的讲解难度。

\section{[参考文献]}

[1]许会.农村初中数学分层教学的策略研究 [J].新课程,2020(37):8.

[2] 居显峰. 初中数学学生自主学习现状与教学优化 [J]. 新课 程,2020(37):46.

[3] 薛永. 问题导学法在初中数学教学中的应用探讨 [J]. 新课 程,2020(37):82.

[4]包环召.初中数学课堂教学中激发学生学习兴趣的有效途径 [J]. 新课程,2020(37):86. 